\title{
THE RIVALRY BETWEEN THE UNITED STATES, CHINA AND RUSSIA IN THE PROCESS OF SHAPING A NEW INTERNATIONAL ORDER IN THE 21ST CENTURY
}

\begin{abstract}
Summary
The purpose of the article is to show the essence and perspectives of the new international order that is emerging in the world, and which is referred to in the literature as the post-Cold War system. In other words, the article includes perspectives and visions of the world in the mid-21st century. In addition, the article is the analysis of the competition and opportunities for cooperation between the United States, China and Russia in the process of shaping the new international system in the world today. The author attempts to show the opportunities and threats for the new order that is emerging in the world, and answer many questions related to this process, including when it will rise and what its shape and character will be. Will it be a democratic and peaceful order, or an undemocratic order, based on rivalry and confrontation between its main subjects, and especially between the great powers, such as the United States, China and Russia?

Keywords: United States, Russia, China, competition, new order, world, perspectives, 21 st century.
\end{abstract}

\section{INTRODUCTION}

The purpose of this article is to attempt to present the essence and perspectives of the international order emerging in the world today, referred to in the literature of the subject as the post-Yalta order, 
post-Communist order or post-Cold War system. In short, the author presents a vision of a new world, which - in author's opinion - will not be shaped until the middle of the 21 st century, and analyses the components that have the most important impact on the character and shape of the new order. In addition, the author attempts to answer the questions that are bothering politicians, experts and scientists today, especially political scientists and researchers of contemporary international relations. These questions are the following: When will this new global order arise and what will its shape and character be, and so, will it be a unipolar, bipolar or multipolar system? Will it be a democratic and peaceful order, or an undemocratic order, based on rivalry and confrontation between its main entities, and especially between the great powers such as the United States, China and Russia? What will happen to the European Union - what will its position and role be in the new global order? Will it be an important subject or just an object?

The Yalta system, or more precisely the Yalta-Potsdam order, which emerged after the end of World War II, actually fell down between 1989 and 1991, when the countries of Central and Eastern Europe regained independence and declared their sovereignty, and the Soviet Union, a state, which next to the United States was the main pillar of the post-war international system in Europe and the world, collapsed. Therefore, this system is called, in the study of international relations as well as by historians, a bipolar or Cold War order. It was undemocratic and was characterised by hostility from both sides that were preparing for the new world war. It was a global order dominated by competition and confrontation in all areas of life, and a Cold War atmosphere prevailed. The arms race, including the atomic one, continued, and preparations for war between the two superpowers and their political and military alliances continued. As a result, during 1945-1991 there were numerous international crises and armed conflicts around the world, such as the Berlin crisis of 1948-1949, the war in Korea in 1950-1953, the Cuban crisis in 1961-1962, or long-lasting Vietnam and Afghan wars that threatened international peace and security. The attempts to resolve these crises failed or brought a brief relaxation in international relations. At that time, there was also a discussion about the end of the Cold War and the development of cooperation between the East and the West, and the construction of a new, peaceful international order. On this wave, the Conference on Security and Cooperation in Europe 
(CSCE) was convened and held in 1971-1975. The conference ended with the signing of the Final Act. There were also various concepts and visions of a safe world, i.e. without conflicts and wars, based on cooperation and widespread disarmament. These ideas were more or less utopian and therefore difficult to implement. They were based on idealistic or constructivist theories. Meanwhile, the history of international relations, including all the global orders, proves that the world functions in accordance with a realistic paradigm. This theory shows that the most important elements of any international system are sovereign states, especially great powers, which have their own particular egoistic goals, for which they do not hesitate to use force and destroy the current international order if it does not meet their expectations. ${ }^{1}$

The collapse of the Soviet Union was a priori perceived by some researchers as the end of the Cold War and post-war history of the world. They announced the beginning of a new era in international relations. As it later turned out, they naively believed that democracy and neoliberalism would eventually prevail in the world; that universal and total disarmament would take place, and universal peace would triumph. Back then, the process of building a new global order began. The process is still ongoing and it is unknown when it will end and what its final shape will be: unipolar, bipolar or multipolar, and will it be able to provide peace and security for the world? Although almost 30 years have passed since the end of the Cold War and the collapse of the Yalta-Potsdam order, which was the result of World War II, we still cannot clearly answer these questions. In the era of changes currently taking place in the world, which are referred to as "sometimes a hegemonic decompression" or an "ingrowing of the rest of the world", ${ }^{3}$ the states that were previously in the "semi-periphery" or even "the periphery" have an increasing influence on the shape of

1 P. Buhlerr, O potedze $w$ XXI wieku (About the power in the 21st century), Wydanictwo Akademickie DIALOG, Warszawa 2014; R. Kuźniar, Polityka i siła. Studia strategiczne zarys problematyki (Politics and power. Strategic studies - outline of issues, Wydawnictwo Naukowe Scholar, Warszawa 2005; H. Morgenthau, Polityka między narodami: walka o potegge i pokój (Politics among nations. The struggle for power and peace), Difin 2010; J. Więcławski, Understanding Realism in Contemporary International Relations. Beyond the Structural Realist Perspective, Nomos Verlagsgesellschaft, Baden-Baden 2019, pp. 78-111.

2 A. Hurrel, Hegemony, liberalism and global order: what space for would-be great powers? "International Affairs" 2006, No. 1, p. 12; F. Fukuyama, Koniec historii (The end of history), Wydawnictwo Zysk i Spółka, Poznań 2000.

F. Zakaria, The post-American Word, Norton, New York 2008, p. 26; R. Kagan, Powrót historii $i$ koniec marzen (Return of history and the end of dreams), Dom Wydawniczy Rebis, Poznań 2009. 
world politics and economy. They break the dominance of existing hegemons and intend to pursue a more autonomous policy, which is not just a function of the interests of great powers, as it was during the Cold War, or in the first decade after the collapse of the Soviet Union, in the era of so-called American unilateralism. Moreover, the arms race has returned to international relations and numerous wars have erupted, for example in Afghanistan, Iraq, Georgia, Syria, and Ukraine, which threaten international security and world peace. Further questions arise here, namely why it happened and why the process of building a new post-Cold War international order is taking so long and its end is still not visible? These questions are also difficult to answer unequivocally today, but this is also the purpose of this article. Before proceeding to further analysis and responding to the questions, the author brings up a general thesis: in the past, all the international orders, following the Peace of Westphalia, the Congress of Vienna, the Treaty of Versailles, and the Yalta and Potsdam conference were shaped after many years of wars on the battlefields of Europe, and were the result of compromise peace treaties concluded between victorious and defeated states. At the same time, the victorious states (the powers) dictated the conditions for the defeated states. These conditions, as a rule, were absolute and very harsh for the defeated countries, and therefore they were the source of new international conflicts and an important element of the next new international order that led to its erosion and collapse.

However, in the years 1989-1991, for the first time in the history of the world, the current order, i.e. the Yalta-Potsdam, fell down not as a result of war, but as an evolutionary route, as a result of the erosion of one of its main pillars, i.e. the bloc of communist states (the East), formed after the Second World War II by the Soviet Union. In the opinion of the author, this is the main reason why the new post-Yalta international system has been shaping for so long. Another reason why the new Yalta global order is still in statu nascendi lies in the fact that the gap that sprung up after the disappearance of the Soviet Union was not and still is not able to be filled either the United States or any other country, such as China, or Russia. ${ }^{4}$ It is only when any of

\footnotetext{
4 P. Wowra, Uwarunkowania mocarstwowości Chin (Return of history and the end of dreams), „Nowa Polityka Wschodnia” 2018, No. 3(18), pp. 77-96; M. Lubina, Russia and China. A Political Marriage of Convenience, Budrich Publishers, Opladen, Berlin 2017; M. Kaczmarski, Russia-China Relations in the Post-Crisis International Order, Routledge, London, New York 2015.
} 
these countries, or all of them, achieve the status of superpower, can the current global order building process be completed, which will eventually be shaped as bipolar or multipolar. For now, this vision is distant, because there are still huge differences of opinion, the arms race and a trade war, which impact the global economy, between China and the United States as well as Russia and the United States.

\section{PREMISES AND CONSEQUENCES OF THE COLLAPSE OF THE YALTA-POTSDAM}

The Yalta and Potsdam conferences, which began on 17 July and ended on 2 August 1945, were to prepare preliminaries for the peace conference, whose main purpose was to adopt and sign a peace treaty with the fascist countries and their satellites, and to establish a new, post-war international order. This did not happen, however, because the peace conference, which was meant to end World War II de jure never took place. ${ }^{5}$ Nevertheless, the Yalta-Potsdam decisions lasted until the "1989 Fall of Nations" and the end of the Cold War. ${ }^{6}$ They became the foundation for the post-war international order (called the Yalta-Potsdam system), which lasted in Europe and in the world until 1989-1991, until the fall of communism in Central and Eastern Europe, the reunification of Germany, and the collapse of the Soviet Union in $1991 .{ }^{7}$ And this is when the Cold War ended, which was a result of the Yalta and Potsdam agreements, and the post-war struggle between the Soviet Union and the United States for world domination. ${ }^{8}$ Central and Eastern European countries regained full

5 On 12 September 1991, West Germany, East Germany and the four former occupation powers signed a treaty on final regulation to Germany, also called the $2+4$ Treaty (United States, Great Britain, USSR and France, as well as West Germany and East Germany), which de facto replaced the peace treaty with Germany provided for in the Potsdam agreement. Also: L. Janicki, B. Koszel, W. Wilczyński (ed.), Zjednoczenie Niemiec. Studia politologiczno-prawne (German reunification. Political and legal studies), Instytut Zachodni, Poznań 1996, pp. 349-373; J. Barcz, Udziat Polski w konferencji 2+4. Aspekty prawne $i$ proceduralne (Poland's participation in the $2+4$ conference. Legal and procedural aspects), PISM, Warszawa 1994; A. Krzemiński, Drugiej Jałty nie było, w: „Polityka”, 16-22.IX.2015, pp. 56-59; M. Jabłonowski, W. Janowski, G. Sołtysiak (ed.), Konferencja dwa plus cztery 1990. Aspekty polskie (1990 two plus four conference. Polish aspects), Wydział Dziennikarstwa, Informacji i Bibliologii Uniwersytetu Warszawskiego, Archiwum Akt Nowych w Warszawie, Fundacja Archiwum Dokumentacji Historycznej PRL, Warszawa 2018.

6 Ibidem.

7 J. Holzer, Europa zimnej wojny (Europe of the Cold War), Wydawnictwo Znak, Kraków 2012, pp. 17-33.

8 Ibidem, pp. 50-95. Also: J.L. Gaddis, Teraz już wiemy ... Nowa historia zimnej wojny (We know now: rethinking Cold War history), Amber, Warszawa 1997. 
sovereignty and were able to exercise their right to self-determination. Poland was the first to use it. It was the chance for Germany to regain full sovereignty and be unified again, which happened on 3 October 1990. As a result of these changes, Europe was given a chance to regain a strong international position on the international stage. It was then that the process of building a new global order began, often called the post-Cold War or post-Communist order. ${ }^{9}$

Under the influence of the "1989 Fall of Nations", there were radical changes in the international system of Europe and the world in the early 1990s. The fall of communism and the collapse of the Soviet Union created a new dynamic global situation, especially in regions that freed themselves from former Soviet geopolitical influences and began their path to integration with the so-called free world. Western countries, led by the United States in the Cold War rivalry, defeated the USSR, which led to the disintegration of the Soviet empire, both internally (USSR) and externally (camp of socialist countries). Both parts of the former Soviet empire adopted different strategies for building their future in the post-Cold War reality. Former socialist countries from the Central European region, including Poland and the GDR , have gradually taken a course on integration with Euro-Atlantic structures - the North Atlantic Alliance (NATO) and the European Union. However, fifteen new independent states emerged in the place of the USSR. Three of them - Lithuania, Latvia and Estonia - were independent states in the interwar period, but were annexed by Moscow during World War II, also began to move westwards. In contrast, the remaining twelve former Soviet Union republics with strong economic and cooperative ties and a unified Soviet political culture during the USSR, established a new structure in place of the USSR - the Commonwealth of Independent States (CIS). The republics wanted to avoid a geopolitical vacuum that would contribute to the deepening of destabilisation of the region (among others the problem of control over the post-Soviet nuclear arsenal, located in the territory of four republics - Russia, Ukraine, Belarus and Kazakhstan). The destabilisation of the region, which is referred to in the study of

9 J.M. Fiszer, System euroatlantycki przed i po zakończeniu zimnej wojny. Istota, cele $i$ zadania oraz rola $w$ budowie nowego ładu globalnego (The Euro-Atlantic system before and after the Cold War. Essence, goals and tasks as well as the role in building a new global order), Instytut Studiów Politycznych PAN, Dom Wydawniczy ELIPSA, Warszawa 2013; J.M. Fiszer (ed.), Gra o świat. W strone nowej Jatty? (Game for the world: Towards the new Yalta?), Instytut Studiów Politycznych PAN, Warszawa 2018; R. Kuźniar, Europa $w$ porzadku miedzynarodowym (Europe in the international order), Polski Instytut Spraw Międzynarodowych, Warszawa 2016. 
international relations as the post-Soviet space, would be dangerous for the world. The CIS was an important element of the post-Cold War international order, but today its role in international relations is of little importance. ${ }^{10}$

In the theoretical aspect, it can be assumed that "an international order is a set of relations, principles, institutions (patterns, behaviours, systems of forces, values) created by participants of international relations, whose joint function is the stability and predictability of their interactions. Therefore, the international order consists of participants of the same kind (actors, elements), structure, i.e. relations, principles and institutions, as well as the material and ideological basis from which it arises and which causes its dynamics and evolution. Its sense lies in its duration, which consists in recreating oneself at higher and higher levels of the structure."11

In the scientific literature there are various definitions of international order and there have been various attempts to describe its essence by philosophers, lawyers, economists, political scientists and historians. They all reflect the longing and dreams of "eternal peace", a world without wars and conflicts between nations and states. Józef Kukułka is right in his thesis that: "Every international order is of a utilitarian nature in the sense that it protects the specific status $q u o$ and the interests of its most important spokespersons. It would be unthinkable that the order would be shaped in such a way to exclude any dynamics of changeability and evolution of the status quo. By promoting certain values, order is a subject to the laws of struggle inherent in these values of opposites, which sets the order in motion and causes its development (subjective, objective and institutional). At the same time, the forces leading to the polarisation of a given order are interested in its institutionalisation, but at a slightly higher level." ${ }^{12}$

The history of international relations, and in particular of all the international orders, shows a common regularity: the opposites that appear in the course of the struggle are specific, depending on the

10 J.M. Fiszer, System euroatlantycki przed i po zakończeniu zimnej wojny. Istota, cele $i$ zadania oraz rola $w$ budowie nowego ładu globalnego (The Euro-Atlantic system before and after the Cold War. Essence, goals and tasks as well as the role in building a new global order), Instytut Studiów Politycznych PAN, Dom Wydawniczy ELIPSA, Warszawa 2013; J. Fiszer, T. Stępniewski, K. Świder, Polska - Europa Wschodnia - Rosja. Obraz politycznej dynamiki regionu (Poland - Eastern Europe - Russia. A picture of the region's political dynamics), Instytut Studiów Politycznych PAN, Warszawa 2019.

11 R. Kuźniar, Porządek międzynarodowy - rewizja koncepcji (International order concept revision), „Sprawy Międzynarodowe” 2017, No. 2, pp. 145-15.

12 J. Kukułka, Wstepp do nauki o stosunkach międzynarodowych (Introduction to the study of international relations), Oficyna Wydawnicza ASPRA-JR, Warszawa 2003, p. 234. 
particular types of international order (a political one, an economic one and others), and the source of the opposites, which can be found at various levels of maturity and levels of internal polarisation, affect general tensions between groups of countries. Conversely, general détente depends on détente in every area of international order, and especially in the areas closest to the basic contradiction between groups of states. Political order is the leading area. As practice shows, political relations are a priority among other types of international relations and there is a synthesis of fundamental international values within them. ${ }^{13}$

\section{THE FORMATION OF A NEW POST-COLD WAR INTERNATIONAL SYSTEM, ITS COMPONENTS AND PERSPECTIVES}

As the author has already mentioned, a radical relaxation in international relations in Europe and in the global balance of power took place after the "1989 Fall of Nations" with the end of the Cold War in 1990-1991. The erosion of basic ideas, values, principles and international structures took shape in subsequent stages of the Yalta-Potsdam order. Thanks to this, the process of building a new international order began, described in the literature on the subject as post-Cold War, or a liberal and democratic order. It was constructed through negotiations of representatives of the old and new regimes. As Józef Kukułka writes: "Confirmation of the beginning of a new order was the cooperation of all powers during the war for Kuwait at the turn of 1990-1991, the adoption of the Charter of the Paris for a New Europe in November 1990, the development of partner institutionalisation of the pan-European process within the framework of the CSCE/OSCE, enriching inter-state relations with the help of non-military means of building trust, and friendship between them by reviving traditional forms of diplomacy and replacing narrow individual or collective security from the mid-1990s with the concept of common and comprehensive security." ${ }^{14}$

The end of the "Cold War" did not, however, solve the problem of European security, nor did it accelerate the process of integration of the former communist bloc countries and the West. Europe had

13 Ibidem, pp. 234-235.

14 Ibidem, p. 238. 
just become a safer place in the world to some extent, but it still was not a continent where all nations could live in the belief that their existence and essential interests were properly protected. That is why it became necessary to accelerate the process of integration of Europe, and to build a new, democratic global order. Poland, reunited Germany and France tried to join this process. Poland, due to its geopolitical and geo-economic location after 1989, was as American secretary of defense William Perry emphasised during his visit to Warsaw in June 1995 - "the key to Europe's security". ${ }^{15}$ Therefore, in 1989-1991, the priority task for Poland was European policy understood as striving to create a pan-European security system and extend Western European integration to all of Europe. The implementation of this goal was to serve, among others proposed at the beginning of 1990 by Prime Minister Tadeusz Mazowiecki, to create a European Cooperation Council. This proposal significantly contributed to the subsequent establishment of the Council of the Conference on Security and Cooperation in Europe (CSCE). Poland's efforts to integrate and cooperate with the European communities corresponded with the pursuit of pan-European integration. ${ }^{16}$

After the reunification in 1990, Germany has strengthened its position on the international arena and has been recognised as a regional power and the main ally of the United States in Europe, and Germany also has perceived cooperation with Poland in building a democratic and secure Europe as a priority task. It was expressed among others in the White Paper published in Bonn in 1994, in which it is emphasised that "democracy, rule of law and prosperity in Europe mean peace and security for Germany too. (...) Germany has greater international responsibility, especially as far as security in and for Europe is concerned (...) Germany has learned the lessons of history and will thus continue to pursue a policy of active integration and broad cooperation". ${ }^{17}$ Volker Ruhe, who was the Minister of Defence

15 J.M. Fiszer, Stosunki polsko- niemieckie po roku 1989 oraz ich znaczenie dla bezpieczeństwa Europy (Polish-German relations after 1989 and their importance for European security), „Studia Polityczne”, No. 5, p. 142.

${ }_{16}$ M. Grela, Paryski szczyt KBWE (CSEC summit in Paris), „Sprawy Międzynarodowe” 1991, No. 2, p. 22; J.J. Węc, Polityka bezpieczeństwa Polski w latach 1989-1995. Wybrane aspekty (Poland's security policy in 1989-1995. Selected aspects), in: E. Cziomer (ed.), Nowy ksztalt bezpieczeństwa europejskiego (New shape of European security), Uniwersytet Jagielloński, Kraków 1996, p. 10.

17 P. Seydak, Biała Ksiega 1994 w sprawie bezpieczeństwa RFN oraz obecnej sytuacji $i$ przyszłości Bundeswehry (White Paper 1994 on the security of the Federal Republic of Germany and the situation and future of the Bundeswehr), „Wojsko i Wychowanie” 1995, No. 10, pp. $72-77$. 
of Germany then, stated that the "White Paper" is "the political and conceptual response of the federal government to the epochal turn of 1989, and fundamental changes in the international system of Europe and the world". ${ }^{18}$

After the reunification in 1990, Germany returned to its traditional role of the Central European power in international politics. Despite this, their raison d'etat continued to be based on deepening ties with the West. The new concept in foreign and security policy set three basic international goals for the federal government: Euro-Atlantic integration and openness to the East, global and regional policy, and policy towards developing countries. The opening to the East referred both to Russia and the post-Soviet states as well as to the countries of Central Europe. The eastern direction in foreign policy is divided into three security zones. Poland and the Czech Republic, as neighbouring countries, were in the first security zone. Hungary, Slovakia, Romania, Bulgaria and post-Yugoslavian states belonged to the second security zone. However, Russia and all post-Soviet countries were in the third security zone. The undoubted increase in Poland's importance in the scale of Eastern policy priorities cannot overshadow the fact that in practical policy Bonn's relations with all the countries of Central and Eastern Europe remained the resultant of relations with Russia. ${ }^{19}$

After some hesitation, France, which feared a reunited Germany and its growing power in Europe, joined the process of building the post-Cold War (post-Communist) international order. The French were in favour of accelerating Europe's integration by first deepening the community, and then expanding it to include the post-communist countries of Central and Eastern Europe. President François Mitterrand was against the enlargement of the community, and including post-communist countries of Central and Eastern Europe, but he advocated the deepening of the community. However, Chancellor Helmut Kohl insisted on expanding the community. As a result, in December 1990, the Community Intergovernmental Conference began, which opened the way to the creation of the European Union. The representatives of the states began to work on a new treaty that went down in the history of European integration under the name of the Maastricht

18 Ibidem, p. 72.

19 D. Bingen, Im Wechselspiel von Stabilitat und Integration. Die politische Bedeutung Deutschlands nach 1990 zwingt zu mehr Verantwortung gegenüber Osteuropa, „Das Parlament”, No. 6/13. September 1996, No. 37-38, p. 14; K. Kaiser und J. Krause (Hrsg.), Deutschlands neue Außpolitik, Interessen und Strategien, Bd. 3, München 1996. 
Treaty. It was signed on 7 February 1992, and entered into force on 1 November 1993. At that time, the European Union, established under this treaty, began its activity and opened a new stage in the process of European integration and building a new international order in the world, becoming one of its main entities.

After the collapse of the communist system in Europe and the end of the Cold War in the world, it was wrongly judged that the greatest threats to international stability in the political sphere, the prosperity of the capitalist system in the economic sphere, and the development of civil society had already disappeared. Communism had disgraced itself in all these spheres, although its fall was primarily determined by the economic sphere, in which the omnipotence of the state brought deplorable results compared to the capitalist system that functioned in the West, and was led by the free market. This situation created favourable opportunities not only for the uncritical implementation of extreme market-oriented economic models in post-communist countries, but also for the emergence of pressure in mature market economies, resulting in minimising the role of the state in shaping economic processes. This pressure had previously found a theoretical basis in the form of a neoliberal doctrine. ${ }^{20}$

Michał Buchowski, the author of a recently published, controversial work entitled "Purgatory. The anthropology of neoliberal post-socialism", expressed its opinion quite unequivocally: "our society as well as the neighbouring societies of the authoritarian communist hell went through the purgatory of democratic reforms" full of racks of economic neoliberalism, through which we come - unlike assumed not to paradise, but (...) back to the hell overfull of false, and this time false of nationalism, false of cultural fundamentalism with its religious overtones and authoritarianism". ${ }^{21}$ Politicians in post-communist countries even thoughtlessly adopted the principles functioning in developed Western societies, considering them to be completely natural and the only right way to arrange the world. We have forgotten that a different level of economy, mentality and management culture require the adaptation of "the only just principles" and account for

${ }^{20}$ More on this: M. Guzek, Świat Zachodu po nieudanym wejściu w ere postindustrialna (The Western World after a failed entry into the post-industrial era), Oficyna Wydawnicza Uczelni Łazarskiego, Warszawa 2018, pp. 22-33; T. Piketty, Kapitał w XXI wieku (Capital in the 21st century), Wydawnictwo Krytyki Politycznej, Warszawa 2015.

${ }_{21}$ M. Buchnowski, Czyściec. Antropologia neoliberalnego postsocjalizmu (Purgatory. Anthropology of neoliberal post-socialism), Poznań 2017, pp. 234-235. 
the status quo, which, after all, creates a number of restrictions and requires many changes. ${ }^{22}$

For thirty years we have been dealing with a unique situation in the world. The Americans have created a unipolar international system and ruled the world. They have had such an economic, institutional, monetary and military advantage that no coalitions were formed to balance against the hegemon. Neither Germany nor Yeltsin Russia, nor China or Japan revolted. In the era of globalisation, the United States have supervised the conditions of the game, which is very beneficial for small and middle-sized countries that do not have to fight for access to raw materials, markets and the international supply chain. ${ }^{23}$

As a result, in the economic sphere, the new international order has been marked by the development of the market system on all continents, but at the same time the phenomenon of asymmetry between rich and poor countries has deepened. Transnational companies and corporations as well as banks, mainly American ones, entered into the equation in international economic relations after 1990, and the role of nation-states, especially middle and small ones, decreased. The world began to move away from building a somewhat diverse and multipolar international order in favour of a unipolar system headed by the United States. Successive presidents of the US spoke louder and louder about the necessary "American leadership in the world". However, the United States' egoistic quest for a unipolar order met with increasing resistance in the world. Numerous politicians accused the United States of hegemonism and unilateralism, of not respecting the rules of democracy and partnership in international relations, and disregarding multilateral international obligations. ${ }^{24}$

What is more, they were right. As Robert Kagan writes: "The liberal order of the world was not really "based on principles", as some say

${ }^{22}$ More on this: P. Załęski, Neoliberalizm i społeczeństwo obywatelskie (Neoliberalism and civil society), Rebus, Poznań 2012; K. Verdery, What Was Socialism, and What Comes Next?, Princeton 1996; W. Morawski, Zmiana instytucjonalna. Społeczeństwo-gospodarka- polityka (Institutional change. Society-economy-politics), PWN, Warszawa 1998.

${ }^{23} \mathrm{~J}$. Bartosiak, Kto będzie rządzić $5 \mathrm{G}$ będzie rzadzić światem (Who will rule $5 \mathrm{G}$ will rule the world), „Gazeta Wyborcza”, 30.06.2019, p. 17.

${ }^{24}$ J. Kukułka, Wstep do nauki o stosunkach międzynarodowych ... (Introduction to the study of international relations), pp. 238-239; J. Stefanowicz, Bezpieczeństwo w Europie lat dziewięćdziesiatych (Security in Europe in the nineties), "Sprawy Międzynarodowe” 1991, No. 5, pp. 7-20; J.M. Fiszer, System euroatlantycki przed i po zakończeniu zimnej wojny. Istota, cele $i$ zadania oraz rola $w$ budowie nowego tadu globalnego (The Euro-Atlantic system before and after the Cold War. Essence, goals and tasks as well as the role in building a new global order), Instytut Studiów Politycznych PAN, Dom Wydawniczy ELIPSA, Warszawa 2013. 
today, at least not in military and strategic matters. The United States, when using force, generally stopped at declarations in the United Nations, and often did not even consult their military interventions with allies". ${ }^{25}$ By the way, this policy is continued today by President Donald Trump, who does what he wants on the international stage. This is demonstrated by, among others, his decisions to withdraw US troops from Syria and Afghanistan, which may hinder the peaceful end to the civil war in these countries and strengthen Russia's influence there. Moreover, it will open "space to terrorist groups to plan operations against US citizens, America and its allies". ${ }^{26}$

On the other hand, Trump says he is not sure if this will continue. He provokes Germany and says that if this order collapses, it is not known whether the ships with their cars will reach the United States or China, and whether it will get oil from the Persian Gulf, because the cruisers and destroyers of the US Navy ensure the safety of its transport. If you still want this world, then adjust to the will of the USA and reform the system so that China does not grow at a pace that leads to its supremacy. ${ }^{27}$

As the author mentions above, after the collapse of the Soviet Union was a good time for Europe and the world, when the United States together with the created European Union could become a leader in building a new multipolar international order. This opportunity, however, was lost, because the United States did not intend to abide by the principle of primus inter pares, striving for the position of the only super actor in the global scene, which was particularly apparent during the presidency of George Bush Junior, who embroiled America in costly wars in Afghanistan and Iraq. ${ }^{28}$ It is reasonable to suppose that "the war with Iraq - apart from other goals - was also to show the world what to expect when the empire (i.e. the US - J.M. Fiszer) decides to strike. (...) President Bush and his team openly say who the master of the world is and announce pre-emptive armed intervention. The security strategy shows what has always been at the heart of US

25 R. Kagan, Koniec Pax Americana?... (The end of Pax Americana?), p. 4.

26 R. Stefanicki, Trump zabiera armie z Afganistanu (Trump withdraws the army from Afganistan), „Gazeta Wyborcza”, 24-26.12.2018, p. 8. Also: E. Eppler, TRUMP - und was tun wir? Der Antipolitiker und die Würde des Politischen, Verlag J.H.W. Dietz Nachf. GmbH, Bonn 2018.

27 J. Bartosiak, Kto będzie rządzić $5 G$ będzie rzadzić światem ... (Who will rule $5 G$ will rule the world), p. 16.

28 The United States spend annually about USD 45 billion only on the war in Afghanistan. Still no effects. More on this: R. Stefanicki, Trump zabiera armie z Afganistanu... (Trump withdraws the army from Afghanistan), p. 8. 
foreign policy (if we include the policy of expansion on the American continent)." 29

The collapse of the Soviet Union meant total victory for the United States in the Cold War. There has also been a loosening of the connections between the capitalist world and American goals. After the threat of communism disappeared, American domination ceased to be a security condition for the existing global order. Potential competition arose in the capitalist world. However, American military advantage over the rest of the world has ruled out such rivalry. The United States then began a kind of game focused on undermining European, prosocial market economies and welfare states. The former Eastern Bloc countries were to play the role of the "Trojan horse". The United States did not hide this goal. It was clearly demonstrated when in January 2003, the Secretary of Defense Donald Rumsfeld contrasted the "old" Europe (France, Germany and other countries opposing American aggression on Iraq) and the "new" Europe (headed by Great Britain), supporting the American attack on Iraq, especially former socialist countries led by Poland. ${ }^{30}$

In September 2002, the Bush administration presented a national security strategy that went down in the history of the United States under the name of the Bush Doctrine. It clearly defined the goals of American foreign policy in the post-Cold War world. The Bush doctrine announced the creation of a new international relations system, with the unquestioned, leading position of the United States. The measures leading to this goal were to push the free market (treated unilaterally as the freedom of American capital to operate in other countries) and to use its own military power. "Today, the United States enjoys a position of unparalleled military strength and has great economic and political influence", he emphasised in this document. This doctrine assumed the possibility of a pre-emptive military attack on another state, including the objective to change the government, which is contrary to international law), as well as the possibility of using nuclear weapons. In addition, the doctrine rejected complying with any treaties or international organisations; it assumed that no real rival who would achieve a larger or even similar military position would appear on the international stage (this element was clearly directed against China); finally, it unambiguously tied in the United States' economic and military policy - "we will not

29 S.G. Kozłowski, Doktryna Busha (The Bush Doctrine), „Dziś” 2003, No. 9, p. 24.

30 Ibidem, pp. 26-27. 
hesitate to act alone, if necessary, to exercise our right to self-defense by acting pre-emptively (...) America will act against emerging threats before they are fully formed". ${ }^{31}$

At the same time, the United States fell into the trap of internal and external debt at the beginning of the 21 st century. The huge debt towards China, estimated at over USD 1.3 trillion, has become particularly dangerous. Moreover, American democracy is floundering and the presidential system is less and less effective, both in internal and foreign policy. On the other hand, Europe, led by the European Union (EU), is becoming increasingly weaker, and has been unable for a long time to deal with the financial and economic crisis and its consequences in many member states of the immigration crisis, Islamic terrorism and many other problems. Meanwhile, there is no doubt that only a strong EU can be a global partner of the United States, which sustains and develops the material and spiritual forces of the Atlantic Community. And a weak Europe, and hence a weak Atlantic Community, will not be the co-creator of the new, clearly multipolar, global order. ${ }^{32}$

Nowadays, most researchers and experts assume that in the perspective of 25-30 years a new multipolar global system will be shaped, in which the emerging powers, including China, India and Russia will play a key role next to the United States. It is assumed that the Euro-Atlantic system will continue to guarantee international security, in which the leading roles will belong to the United States, the European Union and NATO. It is emphasised that the United States will remain a global political, military and economic power, but its hegemonic position will gradually weaken. ${ }^{33}$ French political scientist and diplomat Pierre Buhler in his interesting book ${ }^{34}$ critically assesses the condition of the modern United States and pessimistically

\footnotetext{
${ }^{31}$ Ibidem, p. 27

32 T.G. Ash, Free World: America, Europe and the Surprising Future of the West, Random House, New York 2010; A. Kukliński, K. Pawłowski (ed.), The Atlantic Community. The Titanic of the XXI Century? Wyższa Szkoła Biznesu - National Louis University, Nowy Sacz 2010.

33 P.D. Williams, Security Studies. An Introduction, Routledge, London \& New York 2012; S. Koziej, Między piekłem a rajem. Szare bezpieczeństwo na progu XXI wieku (Between hell and paradise. Security at the beginning of the 21st century), Wydawnictwo Adam Marszałek, Torun 2006; J.W. Müller, Wo Europa endet? Ungarn, Brüssel und das Schicksal der liberalen Demokratie, Suhrkamp, Berlin 2013; J.M. Fiszer, Nowy, pojałtański ład globalny: bipolarny czy multipolarny? (New post-Yalta global order: bipolar or multipolar? An attempt of the forecast), „Biuletyn Analiz i Opinii”, Instytut Studiów Politycznych PAN, No. 01(22), Warszawa 2016, pp. 1-6.

${ }^{34} \mathrm{P}$. Buhler, O potedze $w$ XXI wieku (Power in the 21st Century), Wydawnictwo Akademickie DIALOG, Warszawa 2014.
} 
writes about its further role in the international arena. ${ }^{35} \mathrm{He}$ writes that: "Rightly or wrongly, America is perceived as weakened, because of external and internal debt (...). Despite the debt ceiling set (and subsequently systematically raised) by the US Congress, the projections for the next years are not optimistic - it is estimated that in 2016, US debt will reach an amount of USD 20 trillion, and in 2023 of USD 25 trillion. The figures given above are official estimates of the US government, but other sources are drawing more apocalyptic visions: according to some, US debt will amount to USD 50 trillion (140\% of GDP) in 2030". ${ }^{36}$

It is true: America - which has been maintaining a costly network of bases abroad - since the beginning of the 21 st century has been losing its ability to bear its own debt independently and is forced to rely on foreign debt to finance its debt - nearly half of the US public debt belongs to foreign creditors, mainly China (USD 1.3 trillion) and Japan (USD 1.1 trillion). ${ }^{37}$

The leadership role of the United States in the world has been undermined and criticised for years - not only in economic and political roles, but even in a civilisational one. Theories about the decline of its power have been proclaimed, criticising its internal and foreign policy, both in the United States and outside. The role of this power is anticipated not as a hegemon, but a global driver, and assumes the further development of the power of China and India, as well as some regional powers, and interestingly, Russia's significance in the world is expected to decline. ${ }^{38}$ However, the President of the United States Donald Trump and the President of Russia Vladimir Putin, who is seeking to restore Russia's superpower status and the

35 P.D. Williams, Security Studies. An Introduction, Routledge, London \& New York 2012; S. Koziej, Między piekłem a rajem. Szare bezpieczeństwo na progu XXI wieku (Between hell and paradise. Security at the beginning of the 21st century), Wydawnictwo Adam Marszałek, Torun 2006; J.W. Müller, Wo Europa endet? Ungarn, Brüssel und das Schicksal der liberalen Demokratie, Suhrkamp, Berlin 2013; J.M. Fiszer, Nowy, pojałtański ład globalny: bipolarny czy multipolarny? (New post-Yalta global order: bipolar or multipolar? An attempt of the forecast), „Biuletyn Analiz i Opinii”, Instytut Studiów Politycznych PAN, No. 01(22), Warszawa 2016, pp. 1-6.

${ }^{36}$ P. Buhler, O potędze wXXI wieku... (Power in the 21st Century), p. 262.

37 Ibidem, p. 263.

38 L.W. Zacher, Przyszłość $w$ świetle prognoz światowych u progu XXI wieku (The future in the light of world forecasts at the beginning of the 21st century), in: „Polska 2000 Plus", No. 1, 2001; F. Fukuyama, Budowanie państwa. Władza i ład międzynarodowy $w$ XXI wieku (State-Building: governance and world order in the 21st century), Wydawnictwo REBIS, Poznan 2005; J. Wallerstein, Koniec swiata jaki znamy (The end of the world we know), Wydawnictwo Naukowe PWN, Warszawa 2004; Z. Brzeziński, Wybór-dominacja czy przywództwo (The choice - domination or leadership), Wydawnictwo Znak, Kraków 2004. 
reconstruction of the bipolar or multipolar international order, do not want to let that happen. ${ }^{39}$

Anxiety and attention are also generated by the growth of China, which in 1990 was not in the top ten countries in terms of GDP, but in 2011 it came in second place. What has happened in China since the late 1970s is the largest economic phenomenon in human history. Five hundred and fifty million people moved from villages to cities at that time. The Chinese have built about as much urban space as there is in all of Europe. They are currently building residential space corresponding to that of the Italian capital within a few weeks. Today, China's foreign reserves are over USD 3 trillion and they are the largest creditor of the United States. Forecasts show that in 2025-2030 China will surpass the United States and become the undisputed leader in the global economy. They are already the largest trading power in terms of exports and imports, i.e. they have a great impact on the global economy. In this way, they influence the policy of states not only in their region, but also in Europe and Africa. After forty years of experiments and reforms, China is already a global power, not just a regional or local entity. It is expected to equalise with the United States in military terms by around 2050. To sum up, in the already emerging geopolitical configuration of the world, in the mid-21 st century China will play leading roles in both politics and the economy. It can become a potential alternative to the United States, i.e. become the number one superpower in the world, and even along with the surrounding countries of East Asia - be an alternative to the entire West. ${ }^{40}$

The outstanding sinologist and political scientist Bogdan Góralczyk in his latest book devoted to the Renaissance of China writes that "(...) China is a constant mystery, and also a trap for us. Somehow, contrary

\footnotetext{
39 J.M. Fiszer, System euroatlantyckiw multipolarnym ładzie międzynarodowym: szanse $i$ zagrożenia (The Euro-Atlantic system in the multipolar international order: opportunities and threats), in: J.M. Fiszer, P. Olszewski, B. Piskorska, A. Podraza (ed.), Wspólpraca transatlantycka. Aspekty polityczne, ekonomiczne i spoleczne (Transatlantic cooperation. Political, economic and social aspects), Instytut Studiów Politycznych PAN, Warszawa 2014, pp. 33-52; J.M. Fiszer, Zadania i cele polityki zagranicznej Władimira Putina (Tasks and goals of Vladimir Putin's foreign policy), in: „Myśl Ekonomiczna i Polityczna” 2016, No. 1(52), pp. 167-201.

40 B. Góralczyk, Wielki Renesans. Chińska transformacja i jej konsekwencje (Great Renaissance. Chinese transformation and its consequences), Wydawnictwo Akademickie DIALOG, Warszawa 2018; Z.W. Puślecki, Unia Europejska - Chiny. Nowe zjawiska $w$ stosunkach handlowo-ekonomicznych (European Union - China. New phenomena in trade and economic relations), Wydawnictwo Poznańskie sp. z o.o., Poznań 2018; P. Buhler, O potedze w XXI wieku (Power in the 21st Century), Wydawnictwo Akademickie DIALOG, Warszawa 2014.
} 
to its own name - Zhongguo, i.e. the Middle State - it is not an ordinary state at all. Instead, it is a great and old civilisation that has survived and which has always been governed by its own order and rules. Yes, China was once in the centre of the world and civilisation, and it has been fighting so effectively for the last decades right now. China again wants to be what it used to be for centuries: a great civilisation emanating the world and exerting overwhelming influence on it." ${ }^{4}$

In the future, the United States may become a junior partner for China, as previously Europe was a partner for America. In this way, the rest of the world, including Europe, will find itself on the periphery of a new global order. In each of these scenarios, Europe will be pushed into the background in international relations. Thus, the global triad (USA, China, European Union) as the foundation for a new global order, which was forecast at the beginning of the first decade of the 21 st century, is slowly ceasing to be valid. The vision is of creating the so-called Chimerica, or bipolar order, including America and China. ${ }^{42}$

Forecasts for the European Union are also not very optimistic today. As Roman Kuźniar aptly writes: “(...) the evolution of the international order itself, regardless of the mistakes of the Union itself, reduces its chances of playing a role that was postulated only ten years ago. The deepening of geopolitical pluralism, decentralisation and regionalisation within this order will make the EU - if it fails to use its 'accumulated potential' the way traditional geopolitical actors do - one of the scraps of the global patchwork. The crisis of 2008 and its extensive consequences quickly and dramatically revealed the inability of the EU to effectively influence its immediate environment, which is subject to impulses and changes taking place throughout the international environment. This applies above all to North Africa (the 'Arab spring'), the Middle East conflict, the policy of Turkey and Eastern Europe, and above all Russia, which rejected rapprochement with Europe, set a confrontational course towards it and decided to build an alternative 'Eurasian' union. At the same time, Russia has proved quite effective in breaking the unity of the EU and paralysing its ability to act in the sphere of foreign, security and defence policy." 43

41 B. Góralczyk, Wielki Renesans. Chińska transformacja i jej konsekwencje... (Great Renaissance. Chinese transformation and its consequences), p. 13.

42 R. Kuźniar, Europa $w$ porzadku miedzynarodowym (Europe in the international order), PISM, Warszawa 2016, pp. 208-209; D. Murray, Przedziwna śmierć Europy. Imigracja, tożsamość, islam (The weird death of Europe. Migration, identity, Islam), Zysk i S-ka Wydawnictwo s.j., Poznań 2017.

43 Ibidem, pp. 211-212. 
Everything must be done so that the EU remains an active player on the international stage and plays an important role in building a new international order, and become one of its main pillars. To this end, the unity and cooperation of all states belonging to the European Union, in particular Germany, Poland and France, is necessary. The European Union, which will further be weakened by Brexit, should also cooperate with such informal groupings of countries as the Visegrád Group and the Weimar Triangle. Further cooperation between the EU and the United States, as well as the EU and NATO, is also necessary. If it is not strengthened, then the Euro-Atlantic system will lose its current meaning and cease to be the guarantor of security in the West. ${ }^{44}$

As the author has already mentioned, a new, multipolar international system has been emerging in Europe and in the world since 1991, but has been emerging very slowly and with many question marks as to its final shape. On the other hand, the years 1991-2019 clearly show that the role of the Atlantic Community in the international arena is also weakening. The European Union and NATO have been drifting, and cannot reach a consensus on cooperation and the fight for world peace. Their mutual ties are still not strong. President Donald Trump plays a destructive role in this respect. All this shows that the Atlantic Community was completely unprepared for the collapse of the bipolar order and the collapse of the Soviet empire. It was surprised by the "Arab spring", the war in Syria and events in Ukraine. In the early 1990 s, it was mistakenly assumed that the neoliberal world of free market and democracy would bring solutions that would create a new, wonderful world of freedom, democracy, peace and prosperity, shaped in the image and the resemblance of Pax Americana. The concept of global strategic planning was rejected, as well as the creation of a new Marshall plan or building a new global order. Glorification, even adoration, of neoliberal ideology, turned out to be short-sighted in practice and led the world to an unprecedented financial and economic crisis in 2008-2014, which shook the foundations of democracy and capitalism in the United States and Europe. ${ }^{45}$

${ }^{44}$ T. Clapham, Brexit, czyli walka $z$ tyrania kontynentu (Brexit, i.e. the fight against the tyranny of the continent), „Dziennik Gazeta Prawna”, 27-29.09.2019, p. A24; J. M. Fiszer, Czy brexit przyspieszy rewizję Traktatu Lizbońskiego i uratuje Unię Europejską? (Will Brexit accelerate the revision of the Lisbon Treaty and save the European Union?), „Politeja”, No. 54/2018, pp. 17-43.

45 A. Kukliński, Kryzys Wspólnoty Atlantyckiej XXI w. (21st Century Atlantic Community Crisis), „Biuletyn Polskiego Towarzystwa Ekonomicznego”, No. 2(56), luty 2012, p. 77. Also: 
In relation to the above, many experts claim that the 21 st century will ultimately be the time of all Asian countries, now slowly returning to the centre of the international scene, which they occupied before the period of Western domination. ${ }^{46}$ Nowadays, the reviving Asian powers, led by China, and India and Russia, are increasingly demanding the redefinition of security and the transposition of the liberal democratic world order, i.e. they are in favour of a new multipolar global order. Moreover, the dynamic development of the situation in the region of Asia is today accompanied by a strong imperial ideology and the strategic political interest of Russia as well as closer relations between Beijing and Moscow. On the one hand, Vladimir Putin recognises the advantages of China's diversification of relations and policy in Asia, and on the other hand, he believes that the path to a more secure and influential Russia leads through Beijing and knows that no improvement in relations with other Asian countries would be able to compensate for the deterioration of relations with China. ${ }^{47}$ That is why he is trying to make China be Russia's best friend in the Asia-Pacific region. This, in turn, may result in a broad Russian-Chinese alliance against the hegemony of the United States over the world.

\section{CONCLUSIONS}

In conclusion, the author would like to emphasise once again that World War II radically changed Europe and the world. A new world order, colloquially referred to as Yalta-Potsdam (bipolar), was created from its ruins, and was to be supervised by the United Nations (UN). The UN was established at the end of the World War II and replaced the organisation, which operated in the interwar period - The League of Nations. Now the UN has 196 member states. It became an accelerator of new social, political, economic and international processes in the second half of the 20th century. It accelerated decolonisation

M. Guzek (ed.), Ekonomia i polityka $w$ kryzysie (Economy and politics in crisis), Uczelnia Lazarskiego, Instytut Studiów Politycznych PAN, Dom Wydawniczy ELIPSA, Warszawa 2012.

${ }^{46}$ P. Khanna, The Future is Asian, Simon \& Schuster, New York 2019; A. Acharya, The End of American World Order, Polity Press, Cambridge 2018; M. Falkowski, J. Lang, Zakładnicy Moskwy. Klienci Pekinu: bezpieczeństwo $w$ Azji Centralnej $w$ dobie malejacej roli Zachodu (Moscow Hostages. Beijing's clients: security in Central Asia in the era of the diminishing role of the West), Ośrodek Studiów Wschodnich, No. 51, Warszawa 2014, pp. 25-27.

47 J. Bielecki, P. Rożyński, Ameryka to król kłamstw (America is the king of lies). Interview with Liu Guangyuan, China's ambassador in Warsaw on the 70th anniversary of the PRC, „Rzeczpospolita”, 1.10.2019, p. A23. 
processes in the world, and integration in Europe, which resulted in the emergence of over sixty new sovereign states and the creation of the European Union, which more or less actively participates in the process of creating a new global order. Finally, the 19th century, which was the century of Europe, ended, and the 20th century became the century of the United States and the Soviet Union. Today, these times are slowly going down in history. The Soviet Union disappeared long ago, and the time of US global hegemony is slowly coming to an end. In the opinion of the author, the 21 st century, especially the second half, will probably be the century of Asia and the so-called emerging powers led by China and India. Perhaps Russia will return to the global game if the current (short-sighted) policy of President Vladimir Putin does not lead Russia to economic catastrophe, isolation in the international arena, and eventual collapse, like happened to the Soviet Union. ${ }^{48}$

The changes are accompanied by discussions and disputes among researchers and politicians about the current, transitional and future international order, and about the security of Europe and the whole world. ${ }^{49}$ The current world order is being contested and challenged more and more often. There are questions about the Euro-Atlantic system in the new multipolar international order and the opportunities and threats for Europe and the United States, for the European Union and NATO in the context of progressing globalisation and the growing position of China, India, Russia and Brazil (BRIC), and other regional powers in the world, such as Turkey, Iran, and Pakistan. Further deep reconfiguration of the global scene is therefore inevitable and will continue.

John Ikenberry defines the current shape of the international order as post-hegemonic, heading towards, as he writes, "liberal internationalism 3.0". ${ }^{50}$ Like A. Hurrel, he emphasises the increasing

48 R. Kuźniar, Porzadek międzynarodowy (International Order), „Sprawy Międzynarodowe” 2017, No. 2, pp. 7-27. J.M. Fiszer, Zadania i cele polityki zagranicznej Władimira Putina (Tasks and goals of Vladimir Putin's foreign policy), „Myśl Ekonomiczna i Polityczna” 2016, No. 1(52), pp. 167-201; E. Lucas, Nowa zimna wojna. Jak Kreml zagraża Rosji i Zachodowi (New Cold War. How the Kremlin threatens Russia and the West), Dom Wydawniczy Rebis, Poznań 2008.

49 J.M. Fiszer, System euroatlantycki przed i po zakończeniu zimnej wojny. Istota, cele $i$ zadania oraz rola $w$ budowie nowego ładu globalnego (The Euro-Atlantic system before and after the Cold War. Essence, goals and tasks as well as the role in building a new global order), Instytut Studiów Politycznych PAN, Dom Wydawniczy ELIPSA, Warszawa 2013, pp. 9-16; Z. Brzeziński, Strategiczna wizja. Ameryka a kryzys globalnej potegi (Strategic vision. America and the crisis of global power), Wydawnictwo Literackie, Kraków 2013.

50 G.J. Ikenberry, Liberal internationalism 3.0: America and the dilemmas of liberal Word order, "Perspectives on Politics" 2009, No. 1, pp. 71-87. 
importance of the so-called growing, non-Western countries on the international stage. ${ }^{51}$ In view of the decline of the existing powers and the delegitimisation of the United States' position, the international system is becoming less hierarchical, more and more "flattened" in connection with the "emergence" of countries with influence, and also, on the forum of international organisations, increasingly visible. ${ }^{52}$

The authors of the famous report of the US National Intelligence Council on Global trends 2030. Alternative worlds also predict that in the next two decades the role of middle powers will grow in the world, strengthening their "soft" and "hard" capabilities to shape the global order. Similar forecasts are presented by the American think-tank Atlantic Council in the report entitled Envisioning 2030: US strategy for a post-Western Word, indicating, inter alia, Turkey's role in the regional security system and in shaping global standards and principles..$^{53}$

Today, it is becoming increasingly clear that the emerging new international order is indeed becoming less hierarchical and more horizontal and flattened. Therefore, in addition to the issue of "hard" security, the international community must face many other challenges - social or economic. This in turn opens up opportunities for an active policy of middle powers, i.e. regional powers such as France, Germany, Turkey, Iran and Japan aspiring to conduct foreign policy on a global scale.

With regard to the above, questions arise about the role of the Atlantic Community in shaping the new global order. Is the renaissance of the Atlantic Community possible and will it be able to play a similar role in the 21 st century to that which it played under the aegis of the United States in the 20th century? It can be argued that if the Atlantic Community emerges victorious and strong from the current impasse, it will be a co-creator and a co-actor of the new multipolar international order. If this does not happen, then the world will face years of chaos, conflicts and wars. For neither China nor India will be strong enough for a dozen or even several dozen years to create a new, peaceful international order that bypasses or marginalises the Atlantic Community. ${ }^{54}$

51 A. Hurrel, Hegemony, liberalism and global order..., pp. 12-13.

${ }^{52}$ Ch. Lane, This time it's Real: the end of unipolarity and the Pax Americana, "International Studies Quarterly" 2012, No. 1, pp. 203-209.

${ }_{53}$ Envisioning 2030: US strategy for a post-Western Word, Atlantic Council, New York 2012, pp. 121-127.

54 A. Kukliński, Kryzys Wspólnoty Atlantyckiej... (21st Century Atlantic Community Crisis), p. 80. 
So Zbigniew Brzezinski is right as he writes in his significant book "Strategic Vision. America and the crisis of global power": "Only a dynamic, following a well thought-out strategy, can America, together with a unifying Europe, cooperate for a larger and more vital West, which will be able to play a responsible role as a partner for a growing and more and more confident East. Otherwise, it cannot be ruled out that the geopolitically divided and self-centred West will plunge into a historic decline that will be likened to the humiliated and powerless 19th-century China. In the East, there will be a temptation to repeat the catastrophic result of a test of power between the countries of 20th-century Europe." 55

In fact, agreeing with these theses, it should be added that the world also needs the European Union and NATO, i.e. it needs a strong and efficient Euro-Atlantic system and a reformed and effective UN. It also needs a modern and democratic Russia and China. Therefore, everything should be done to ensure that these entities do not disappear from the international arena and cooperate with each other in efforts to strengthen international security and build a new, democratic, multipolar global order. Furthermore, the promotion of democratisation and polarity in international relations as well as peace and equal cooperation should become the goal of each country's foreign policy. This is the only way to prevent another, third, world war, which is becoming more and more realistic today.

55 Z. Brzeziński, Strategiczna wizja. Ameryka a kryzys globalnej potęi... (Strategic vision. America and the crisis of global power), p. 10. 